\title{
HUBUNGAN ILMU NEGARA DENGAN HUKUM TATA NEGARA
}

\author{
ARY ABDUL HAFIDZ \\ aryabdulhafidz2020@gmail.com \\ 2010003600134 \\ UNIVERSITAS EKA SAKTI
}

A. PENDAHULUAN

Ilmu Negara dengan Hukum Tata Negara sangat berkaitan erat satu sama lainnya. Hal ini bisa dilihat berdasarkan objeknya yaitu Negara.

Tentunya muncul pertanyaan di manakah letak hubungan antara kelelahan?

Hubungan tersebut dapat dilihat dari berbagai uraian berikut:

Ilmu negara yang pertama kali diperkenalkan oleh George Jellinek sebagai ilmu pengetahuan yang mempelajari tentang pokok dan sendi-sendi pokok tentang negara dapat dijadikan dasar teori yang bersifat umum bagi hukum tata negara.

Kata umum tersebut menunjukkan bahwa dasar kajian dari Ilmu Negara mencakup hal-hal yang bersifat umum, seperti teori terbentuknya negara, sifat dan hakikat negara, unsur-unsur negara, bentuk-bentuk negara, tujuan dan fungsi negara yang semuanya itu merupakan asas-asas pokok .

Inilah yang menempatkan ilmu negara sebagai staatwisssenchaften. 
Uraian di atas menunjukkan bahwa Ilmu Negara akan menjadi kiblat terbentuknya Hukum Tata Negara dan Hukum-hukum lainnya yang ada di lungkup negara.

Keadaan negara ini dapat direfleksikan dengan sebuah pohon, di mana ilmu negara menjelaskan kriteria-kriteria sehingga dapat dikatakan pohon bukan bunga atau sayuran, sedangkan Hukum Tata Negara akan menjelaskan struktur-struktur dari pohon tersebut, seperti daun, batang, akar serta fungsi-fungsinya -masing.

Oleh karena itu dapat dikatakan bahwa sebelum mempelajari hukum tata negara, maka terlebih dahulu harus memiliki pengetahuan secara umum tata negara yang dapat dari ilmu negara. Dapat dibagi bahwa ilmu negara merupakan ilmu dasar pokok Hukum Tata Negara.

Hukum Tata Negara merupakan penerapan konkret dari teori-teori yang dihasilkan oleh ilmu negara. 


\section{B. PEMBAHASAN}

Hubungan Hukum Tata Negara dengan Ilmu Negara

Keduanya mempunyai hubungan yang sangat dekat, Ilmu Negara mempelajari : 1) Negara dalam

pengertian abstrak artinya tidak terikat waktu dan tempat, 2) Ilmu Negara mempelajari konsep konsep dan teori-teori mengenai Negara serta hakekat Negara. Sedangkan Hukum Tata Negara mempelajari : 1) Negara dalam keadaan konkrit artinya Negara yang sudah terikat waktu dan tempat, 2) Hukum Tata Negara mempelajari Hukum Positif yang berlaku dalam suatu Negara. 3) Hukum Tata Negara mempelajari Negara dari segi struktur.

Hubungan HTN dengan ilmu negara dilihat dari :

a. Kedudukannya: 1) Ilmu negara merupakan pengantar bagi HTN dan HAN. 2) Ilmu negara, ilmu teoritis-ilmiah yang akan dipraktekan dalam HTN.

b. Manfaatnya (Rengers Hora Sicama):

Dilihat tugas ahli hukum: Ilmu negara sebagai penyelidik yang hendak mendapatkan kebenaran-kebenaran secara obyektif. IImu negara tidak melaksanakan hukum, sedangkan HTN sebagai pelaksana hukum.

Dilihat dari objek kajian: IImu negara obyek penyelidikannya adalah asas-asas pokok dan pengertian-pengertian pokok tentang negara pada 
umumnya à sein wissenschaft.

Sedangkan HTN objeknya adalah hukum positif à normativen wissenschaft.

Dengan demikian hubungan antara Ilmu Negara dengan Hukum Tata Negara adalah Ilmu Negara adalah dasar dalam penyelenggaraan praktek ketatanegaraan yang diatur dalam Hukum Tata

Negara lebih lanjut dengan kata lain Ilmu Negara yang mempelajari konsep, teori tentang Negara

merupakan dasar dalam mempelajari Hukum Tata Negara.

\section{PENUTUP}

Ilmu Negara dengan Hukum Tata Negara sangat berkaitan erat satu sama lainnya. Hal ini bisa dilihat berdasarkan objeknya yaitu Negara. hubungan antara IImu Negara dengan Hukum Tata Negara adalah Ilmu Negara adalah dasar dalam penyelenggaraan praktek ketatanegaraan yang diatur dalam Hukum Tata negara. Oleh karena itu dapat dikatakan bahwa sebelum mempelajari hukum tata negara, maka terlebih dahulu harus memiliki pengetahuan secara umum tata negara yang dapat dari ilmu negara. Dapat dibagi bahwa ilmu negara merupakan ilmu dasar pokok Hukum Tata Negara. 


\section{DAFTAR PUSTAKA}

Darmini Roza dan Laurensius Arliman S Peran Pemerintah Daerah Di Dalam Melindungi Hak Anak Di Indonesia, Masalah-Masalah Hukum, Volume 47, Nomor 1, 2018.

Laurensius Arliman S, Komnas HAM dan Perlindungan Anak Pelaku Tindak Pidana, Deepublish, Yogyakarta, 2015.

Laurensius Arliman S, Penguatan Perlindungan Anak Dari Tindakan Human Trafficking Di Daerah Perbatasan Indonesia, Jurnal Selat, Volume 4, Nomor 1, 2016.

Laurensius Arliman S, Problematika Dan Solusi Pemenuhan Perlindungan Hak Anak Sebagai Tersangka Tindak Pidana Di Satlantas Polresta Pariaman, Justicia Islamica, Volume 13, Nomor 2, 2016.

Laurensius Arliman S, Pelaksanaan Perlindungan Anak Yang Tereksploitasi Secara Ekonomi Oleh Pemerintah Kota Padang, Veritas et Justitia, Volume 2, Nomor 1, 2016.

Laurensius Arliman S, Kedudukan Ketetapan MPR Dalam Hierarki Peraturan 
Perundang-Undangan Di Indonesia, Lex Jurnalica, Volume 13, Nomor 3, 2016.

Laurensius Arliman S, Komnas Perempuan Sebagai State Auxialiary Bodies Dalam Penegakan Ham Perempuan Indonesia, Justicia Islamica, Volume 14, Nomor 2, 2017.

Laurensius Arliman S, Peranan Pers Untuk Mewujudkan Perlindungan Anak Berkelanjutan Di Indonesia, Jurnal Ilmu Hukum Tambun Bungai, Volume 2, Nomor 2, 2017.

Laurensius Arliman S, Mewujudkan Penegakan Hukum Yang Baik Untuk Mewujudkan Indonesia Sebagai Negara Hukum, Jurnal Hukum Doctrinal, Volume 2, Nomor 2, 2017.

Laurensius Arliman S, Participation Non-Governmental Organization In Protecting Child Rights In The Area Of Social Conflict, The 1st Ushuluddin and Islamic Thought International Conference (Usicon), Volume 1, 2017.

Laurensius Arliman S, Partisipasi Masyarakat Dalam Pembentukan Perundang- Undangan Untuk Mewujudkan Negara Kesejahteraan Indonesia, Jurnal Politik Pemerintahan Dharma Praja, Volume 10, Nomor 1, 2017, https://doi.org/10.33701/jppdp.v10i1.379.

Laurensius Arliman S, Peran Komisi Perlindungan Anak Indonesia Untuk Mewujudkan Perlindungan Anak, Jurnal Respublica Volume 17, Nomor 2, 2018.

Laurensius Arliman S, Menjerat Pelaku Penyuruh Pengrusakan Barang Milik Orang Lain Dengan Mempertimbangkan Asas Fungsi Sosial, Jurnal Gagasan Hukum, Volume 1, Nomor 1, 2019.

Laurensius Arliman S, Ilmu Perundang-Undangan Yang Baik Untuk Negara Indonesia, Deepublish, Yogyakarta, 2019.

Laurensius Arliman S, Isdal Veri, Gustiwarni, Elfitrayenti, Ade Sakurawati, Yasri, Pengaruh Karakteristik Individu, Perlindungan Hak Perempuan Terhadap Kualitas Pelayanan Komnas Perempuan Dengan Kompetensi Sumber Daya Manusia Sebagai Variabel Mediasi, Jurnal Menara Ekonomi: Penelitian dan Kajian IImiah Bidang Ekonomi, Volume 6, Nomor 2, 2020.

Laurensius Arliman S, Pendidikan Kewarganegaraan, Deepublish, Yogyakarta, 2020.

Laurensius Arliman S, Makna Keuangan Negara Dalam Pasal Pasal 23 E Undang-Undang Dasar 1945, Jurnal Lex Librum, Volume 6, Nomor 2 Juni 2020, http://dx.doi.org/10.46839/lljih.v6i2.151.

Laurensius Arliman S, Kedudukan Lembaga Negara Independen Di Indonesia Untuk Mencapai Tujuan Negara Hukum, Kertha Semaya Journal Ilmu Hukum, Volume 8, Nomor 
Laurensius Arliman S, Pelaksanaan Assesment Oleh Polres Kepulauan Mentawai Sebagai Bentuk Pelaksanaan Rehabilitasi Bagi Pecandu Dan Korban Penyalahgunaan Narkotika, Jurnal Muhakkamah, Volume 5, Nomor 1, 2020.

Laurensius Arliman S, Aswandi Aswandi, Firgi Nurdiansyah, Laxmy Defilah, Nova Sari Yudistia, Ni Putu Eka, Viona Putri, Zakia Zakia, Ernita Arief, Prinsip, Mekanisme Dan Bentuk Pelayanan Informasi Kepada Publik Oleh Direktorat Jenderal Pajak, Volume 17, No Nomor, 2020.

Larensius Arliman S, Koordinasi PT. Pegadaian (Persero) Dengan Direktorat Reserse Narkoba Polda Sumbar Dalam Penimbangan Barang Bukti Penyalahgunaan Narkotika, UIR Law Review, Volume 4, Nomor 2, 2020, https://doi.org/10.25299/uirlrev.2020.vol4(1).3779.

Laurensius Arliman S, Tantangan Pendidikan Kewarganegaraan Pada Revolusi 4.0, Ensiklopedia Sosial Review, Volume 2, Nomor 3, 2020.

Muhammad Afif dan Laurensius Arliman S, Protection Of Children's Rights Of The Islamic And Constitutional Law Perspective of The Republic Of Indonesia, Proceeding: Internasional Conference On Humanity, Law And Sharia (Ichlash), Volume 1, Nomor 2, 2020.

Otong Rosadi danLaurensius Arliman S, Urgensi Pengaturan Badan Pembinaan Idelogi Pancasila Berdasarkan Undang-Undang Sebagai State Auxiliary Bodies yang Merawat Pancasila dalam Perspektif Hak Asasi Manusia, Prosiding Konferensi Nasional Hak Asasi Manusia, Kebudayaan dan Tujuan Pembangunan Berkelanjutan Indonesia pada Masa Pandemi Covid-19: Tantangan untuk Keilmuan Hukum dan Sosial Volume 1, Universitas Pancasila, Jakarta, 2020. 